\title{
Potassium extraction from the silicate rock Verdete using organic acids
}

\author{
Lorrane Marques Duarte $^{1 \oplus}$, Laura Vieira Xavier ${ }^{1}$, Kamila Fernanda Rossati1® ${ }^{\circledR}$, Vinícius Amaral de Oliveira ${ }^{1}$, Raquel Stavale \\ Schimicoscki2 ${ }^{2}$, Cícero Naves de Ávila Neto ${ }^{2}$, Gilberto de Oliveira Mendes ${ }^{1 *} \mathbb{C}$
}

\author{
'Universidade Federal de Uberlândia/Instituto de Ciências \\ Agrárias - Lab. de Microbiologia e Fitopatologia, Rod. LMG- \\ 746, km 1 - Bloco 1B-MC - 38500-000 - Monte Carmelo, \\ MG - Brasil. \\ 2Universidade Federal de Uberlândia - Faculdade de \\ Engenharia Química, Av. João Naves de Ávila, 2121 - Bloco \\ 1K - 38400-902 - Uberlândia, MG - Brasil. \\ *Corresponding author <gilbertomendes@ufu.br>
}

Edited by: Tiago Osório Ferreira

Received June 02, 2020

Accepted January 15, 2021
ABSTRACT: Although Brazil is one of the world's leading exporter of agricultural products, the country is highly dependent on the importation of potassic fertilizers. K-bearing silicate rocks are reported as potential solutions to reduce external $\mathrm{K}$ dependency. This work evaluated $\mathrm{K}$ extraction from silicate Verdete rock, a glauconite-bearing rock containing $10 \%$ of $\mathrm{K}_{2} \mathrm{O}$, by solubilization with organic acids. Firstly, Verdete rock was reacted during 3-120 h with solutions of citric or oxalic acid at $2 \%(\mathrm{~m} / \mathrm{v})$ in Erlenmeyer flasks by shaking. Oxalic acid extracted $6.5 \%$ of $\mathrm{K}$ in Verdete, while citric acid extracted $2.3 \%$. Another experiment was performed to evaluate the effect of various oxalic acid concentrations $(2,4,6,8$, and $10 \%)$ and differing reaction times $(12,24,48$, and $72 \mathrm{~h})$ on $\mathrm{K}$ extraction from Verdete rock. Soluble $\mathrm{K}$ concentration nearly doubled with the increase of reaction time from 12 to $72 \mathrm{~h}$, rising from 20 to $37 \mathrm{mg} \mathrm{L}^{-1}$. Increments in $\mathrm{K}$ extraction were obtained by increasing oxalic acid concentrations up to $6 \%$ and above this concentration, no significant gain was observed. The X-ray diffraction data showed that $\mathrm{K}$ extraction resulted from the formation of oxalate-metal complexes with metals in Verdete rock.

Keywords: glauconite, bioleaching, oxalate, fertilizer

\section{Introduction}

Potassium $(\mathrm{K})$ is a critical nutrient for croplands worldwide. Although Brazil is considered a 'global farm' (Tollefson, 2010), most potash fertilizer applied in Brazilian agriculture is imported (ANDA, 2017). Therefore, freight costs greatly affect prices, an issue shared by other tropical countries in the southern hemisphere (Ciceri et al., 2017; Manning, 2018). The development of technologies that enable the exploration of local K sources to substitute imports can reduce costs.

Brazil has been depleting $\mathrm{K}$ reserves of potash ores of high solubility, such as sylvinite $(\mathrm{KCl} / \mathrm{NaCl}$ mixture) and carnallite $\left(\mathrm{KCl}^{\mathrm{MgCl}} \cdot \mathrm{MgH}_{2} \mathrm{O}\right)$ (DNPM, 2018). Nevertheless, there are large reserves of easily extractable K-silicate rock resources near the soil surface, such as Verdete rock, which contains around $10 \% \mathrm{~K}_{2} \mathrm{O}$ and its reserves are estimated at $10^{8} \mathrm{t}$ (Luz et al., 2010; Safatle et al., 2020; Santos et al., 2015a). Since Brazilian deposits of soluble $\mathrm{K}$ sources supply less than $10 \%$ of the demand for $\mathrm{K}$, silicate rocks, such as Verdete rock, have been suggested as alternative $\mathrm{K}$ sources for agriculture (Luz et al., 2010; Santos et al., 2015a). However, due to the low solubility, these K-rich silicate rocks need physical, chemical, or biological treatment to make $\mathrm{K}$ available to plants in a short term (Ciceri et al., 2017; Matias et al., 2019; Santos et al., 2015b). Most of these treatments rely on high temperatures to achieve $\mathrm{K}$ solubilization (Ciceri and Allanore, 2020; Santos et al., 2015a), which is energetically unfavorable.

Microorganisms have been proposed as an alternative to produce soluble $\mathrm{K}$ fertilizer from K-rich silicate rocks (Lopes-Assad et al., 2010; Matias et al., 2019; Xue et al., 2019) or as soil inoculants to improve $\mathrm{K}$ availability to plants (Maity et al., 2014; Zhang and Kong, 2014). Citric and oxalic acids are microbial metabolites involved in the biochemical weathering of rocks and minerals (Gadd, 1999, 2007, 2017a). These organic acids can weaken the mineral structure and release rock components through acidulation and complexation of cations (Gadd, 2017a; Stumm, 1986). There are reports on citric acid as a $\mathrm{K}$ extractor from K-bearing silicate rocks (Pessoa et al., 2015; Santos et al., 2015a); however, information on oxalic acid effectiveness is scarce. Citric and oxalic acid could possibly dissolve minerals in Verdete rock and thus release $\mathrm{K}$. This research evaluated $\mathrm{K}$ extraction from Verdete rock using organic acids involved in mineral solubilization.

\section{Materials and Methods}

\section{K source}

Verdete samples were collected from a rock outcrop on the border between the municipalities of Quartel Geral and Serra da Saudade, in Minas Gerais State, Brazil (19 17'59.0"

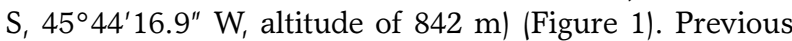
works have characterized Verdete as a sedimentary rock composed mainly by glauconite (40-80\%), whose origin may be related to marine transgression, resulting in diagenetic substitution with $\mathrm{K}^{+}$into clay minerals (Moreira et al., 2016; Safatle et al., 2020).

The rocks were ground in a hammer mill and sieved to obtain particle size of $\leq 74 \mu \mathrm{m}$ (200 mesh). The chemical composition of Verdete rock (Table 1) was previously determined by X-ray fluorescence (XRF) (Schimicoscki et al., 2020). Mineralogical characterization by X-ray diffraction (XRD) indicated that Verdete rock is composed mainly by aluminosilicates, with typical diffraction peaks of $\mathrm{K}$ feldspar, mica (muscovite and glauconite), and quartz (Safatle et al., 2020). The loss on ignition was $4 \%$. 


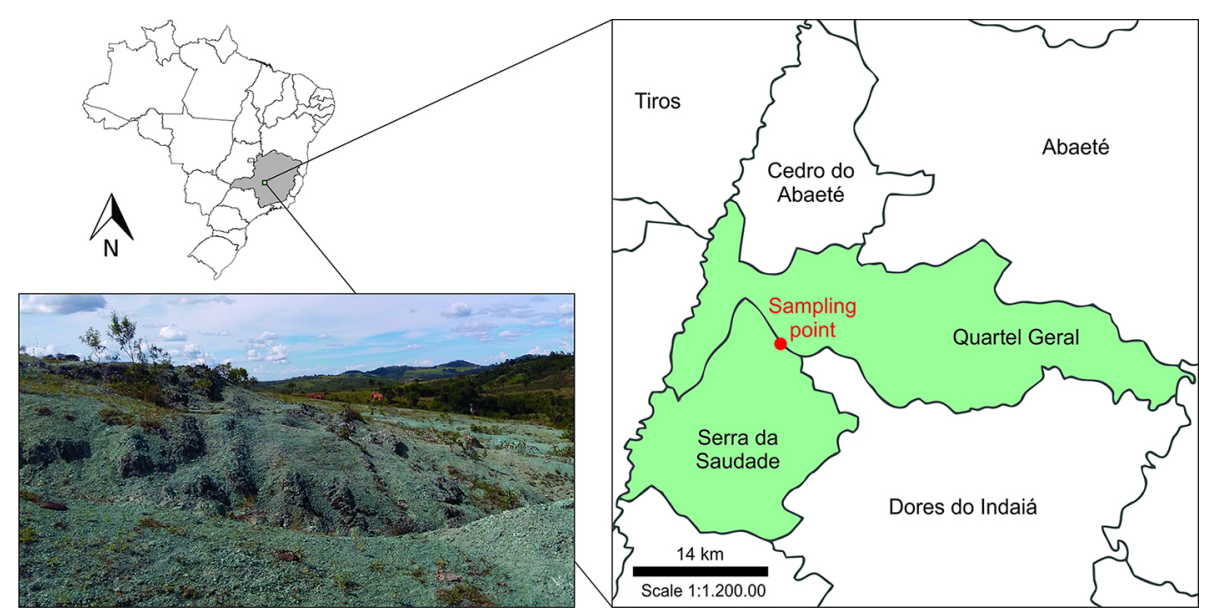

Figure 1 - Location map showing a detailed view of the municipalities where the Verdete samples were collected (red circle). The bottom left panel shows a picture of the outcrop.

Table 1 - Chemical composition of Verdete rock.

\begin{tabular}{lc}
\hline Compound & Mass fraction \% \\
\hline $\mathrm{SiO}_{2}$ & 60.29 \\
$\mathrm{Al}_{2} \mathrm{O}_{3}$ & 16.04 \\
$\mathrm{~K}_{2} \mathrm{O}$ & 11.28 \\
$\mathrm{Fe}_{2} \mathrm{O}_{3}$ & 7.36 \\
$\mathrm{MgO}$ & 3.10 \\
$\mathrm{Br}$ & 1.35 \\
$\mathrm{TiO}_{2}$ & 0.93 \\
$\mathrm{~V}_{2} \mathrm{O}_{5}$ & 0.12 \\
$\mathrm{P}_{2} \mathrm{O}_{5}$ & 0.09 \\
$\mathrm{Rb}_{2} \mathrm{O}$ & 0.06 \\
$\mathrm{MnO}^{\mathrm{Z} O} \mathrm{Z}_{2}$ & 0.05 \\
$\mathrm{ZnO}^{\mathrm{N} O} \mathrm{O}_{2}$ & 0.03 \\
$\mathrm{NiO}$ & 0.02 \\
\hline
\end{tabular}

Data obtained from Schimicoscki et al. (2020).

\section{K extraction from Verdete rock with organic acids}

We performed a first experiment to compare the efficiency of citric and oxalic acids to extract $\mathrm{K}$ from Verdete rock. The reactions were carried out in 125$\mathrm{mL}$ Erlenmeyer flasks containing $0.4 \mathrm{~g}$ of Verdete rock and $40 \mathrm{~mL}$ of $2 \%(\mathrm{~m} / \mathrm{v})$ aqueous solutions of citric or oxalic acids. Acid concentration was based on Pessoa et al. (2015) applying $2 \%$ of citric acid as an extractant for K-bearing ores. The flasks were sealed with parafilm and placed in an orbital shaker at $150 \mathrm{rpm}$ and $30^{\circ} \mathrm{C}$. Three flasks were taken at 3, 6, 9, 12, 24, 48, 72, 96, and $120 \mathrm{~h}$ and the content was filtered through quantitative filter paper (pores $25 \mu \mathrm{m}, 80 \mathrm{~g} \mathrm{~m}^{-2}$ ). The concentration of soluble $\mathrm{K}$ was determined by flame photometry. Controls consisted of flasks containing Verdete and distilled water. The initial solution was kept throughout the entire experiment.
As oxalic acid performed better in the first experiment, another assay was carried out to evaluate the effect of oxalic acid concentration $(2,4,6,8$, and $10 \%)$ and the reaction time $(12,24,48$, and $72 \mathrm{~h})$ on $\mathrm{K}$ extraction from Verdete rock. The two factors were combined in a $5 \times 4$ factorial scheme. The reactions were carried out in the same conditions described above. At each collection time, three flasks were taken and the content was vacuum filtered through a 0.45 $\mu \mathrm{m}$ membrane. The insoluble fraction retained on the membrane was collected and analyzed by XRD. The concentration of soluble $\mathrm{K}$ in the filtrate was determined by flame photometry.

\section{XRD analyses}

Powder samples of three repetitions were combined for the analyses. XRD was performed in a Shimadzu XRD $6000 \mathrm{X}$-ray diffractometer, applying $\mathrm{Cu} \mathrm{K} \alpha$ radiation $(\lambda$ $=1.54056 \AA$ ) and operated at $30 \mathrm{~mA}$ current and 40.0 $\mathrm{kV}$ voltage. Scans were performed continuously from $5^{\circ}$ to $55^{\circ} 2 \theta$ with a rate of $2^{\circ} \mathrm{min}^{-1}$. Diffractograms of samples were compared to diffraction peaks of Verdete rock and to standard peaks obtained in the Inorganic Crystal Structure Database (ICSD) (K-feldspar 10270, muscovite 74608, and quartz 174) and to the American Mineralogist Crystal Structure Database (AMCSD) (glauconite 5026). XRD scans were shown in relative intensities; therefore, no quantitative estimates were carried out.

\section{Chemical equilibrium modeling}

We conducted a simulation in the software Visual MINTEQ 3.1 to estimate the concentration and activity of the main chemical species formed between metals in Verdete rock and oxalic acid. All chemical components of Verdete rock (Table 1) were included in the simulation at 
amounts corresponding to the concentration of Verdete used in the experiments, that is, $1 \%(\mathrm{~m} / \mathrm{v})$. Oxalate was included at $2 \%(\mathrm{~m} / \mathrm{v})$. Visual MINTEQ was run using the following settings: $\mathrm{pH}$ calculated from mass balance, ionic strength fixed at 0.01 , temperature $25^{\circ} \mathrm{C}$, activity correction by Debye-Hückel method, and oversaturated solids were allowed to precipitate, only after the final answer was reached. The other parameters were kept as software standards.

\section{Statistical analyses}

The experiments were conducted in a completely randomized design (CRD) with three repetitions per treatment. The data were subjected to the regression analysis. The significance of coefficients was analyzed by the $t$ test $(p<0.01)$. A response surface model (RSM) was fitted using the experiment data with different oxalic acid concentrations and reaction times. RSM was performed to study the combined effect of both factors on $\mathrm{K}$ extraction and fit a multiple regression model (Myers et al., 2016). Non-significant coefficients ( $p>$ $0.1)$ were removed from the model (Mendes et al., 2013). The Minitab 18 software was used for the RSM analysis and for the creation of the contour plot.

\section{Results}

Oxalic acid provided the highest concentration of soluble $\mathrm{K}$, reaching an extraction of $6.5 \%\left(60.5 \mathrm{mg} \mathrm{K} \mathrm{L}^{-1}\right)$ of $\mathrm{K}$ in Verdete rock (Figure 2). Citric acid, in turn, allowed only $2.3 \%$ (22 $\left.\mathrm{mg} \mathrm{K} \mathrm{L}^{-1}\right)$ of $\mathrm{K}$ extraction. The control with distilled water presented $3.6 \mathrm{mg}$ soluble $\mathrm{K} \mathrm{L}^{-1}$ The kinetics of $\mathrm{K}$ extraction was different between the acids. The reaction with oxalic acid was faster, presenting an exponential rise of soluble $\mathrm{K}$ until reaching a plateau after $48 \mathrm{~h}$. On the other hand, citric acid showed a linear increase in soluble $\mathrm{K}$ in the timeframe evaluated.

Oxalic acid was further investigated for its influence of the concentration and reaction time on $\mathrm{K}$ extraction from Verdete rock. Both variables significantly affected $\mathrm{K}$ extraction; however, the variables did not interact significantly $(p=0.73)$. Regardless of oxalic acid concentrations, the longer the reaction time, the greater the amount of solubilized $\mathrm{K}$ (Figure 3A). On the other hand, increasing oxalic acid concentration was only efficient up to $6 \%$. Above this concentration, there was no more significant increment of the soluble $\mathrm{K}$ concentration (Figure 3B). The model fitted by RSM $\left[\mathrm{K}\left(\mathrm{mg} \mathrm{L}^{-1}\right)=10.02+0.729\right.$ oxalate $(\%)+0.2976$ time (h)] had a determination coefficient $\left(\mathrm{R}^{2}\right)$ of $88.1 \%$. The contour plot clearly showed that the reaction time had more influence on the amount of solubilized $\mathrm{K}$ than the oxalic acid concentration (Figure $3 \mathrm{C}$ ).

XRD patterns showed that Verdete rock was composed of K-feldspar, micas (muscovite and glauconite), and quartz (Figure 4). The main diffraction peaks attributed to K-feldspar $(\psi)$ were located at $20.9^{\circ}$, $23.5^{\circ}, 25.7^{\circ}, 26.7^{\circ}, 27.6^{\circ}, 41.8^{\circ}$, and $50.8^{\circ}$. XRD peaks corresponding to muscovite $(\mu)$, phyllosilicate of the mica group, was found at $8.9^{\circ}, 17.8^{\circ}, 19.6^{\circ}, 29.8^{\circ}$, $34.7^{\circ}, 37.0^{\circ}, 42.5^{\circ}$, and $45.5^{\circ}$. Most XRD lines for glauconite overlapped those of muscovite. However, the greenish color and softness, due to a laminar structural organization, indicate that the rock was also composed of glauconite (Safatle et al., 2020). XRD peaks at $20.7^{\circ}$ and $26.5^{\circ}(\theta)$ demonstrated the presence of quartz.

The XRD patterns of the reaction products were very similar to the XRD pattern of Verdete rock (Figure 4). Characteristic peaks of K-feldspar, micas, and quartz were all present, with similar intensities and widths at half height. Peaks of $9^{\circ}, 17.8^{\circ}$, and $45.5^{\circ}$, attributed to micas, showed a relative decrease compared to Verdete with increasing time and oxalic acid concentrations, suggesting a change in the crystal structure of these minerals. Perhaps the most interesting fact is the appearance of peaks at $18.7^{\circ}$ and $28.9^{\circ}$, represented by $\alpha$ (upper right corner of Figure 4), and possibly related to formation on oxalate-metal complexes.

\section{Discussion}

In this research, oxalic and citric acids were tested as reactants for $\mathrm{K}$ extraction from Verdete rock. Reaction

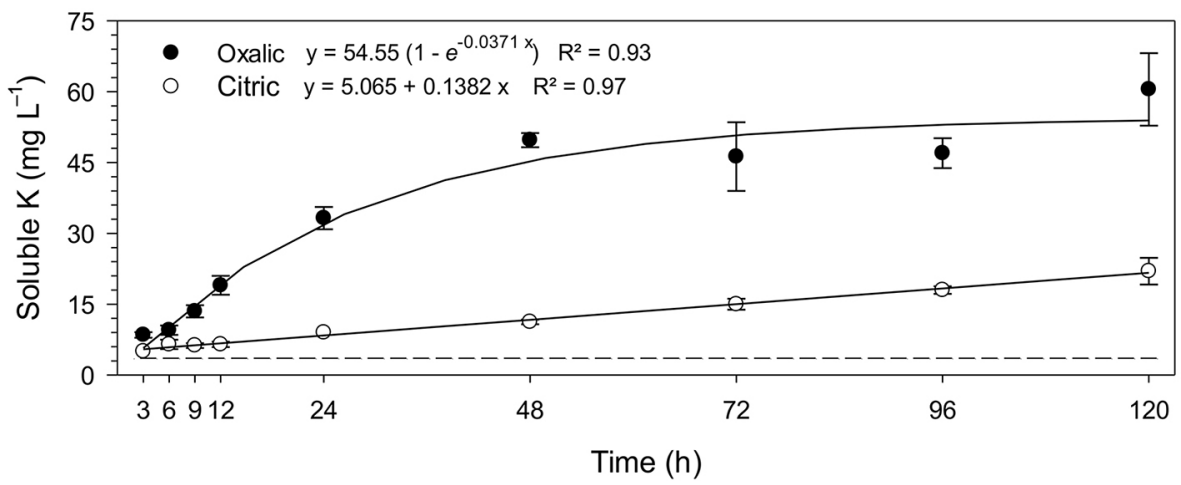

Figure 2 - Solubilized K from Verdete incubated during $120 \mathrm{~h}$ with a $2 \%$ solution of oxalic or citric acid. The dashed line represents control with distilled water. Error bars represent standard deviation $(n=4)$. All regression coefficients are significant $(t$ test, $p<0.01)$. 

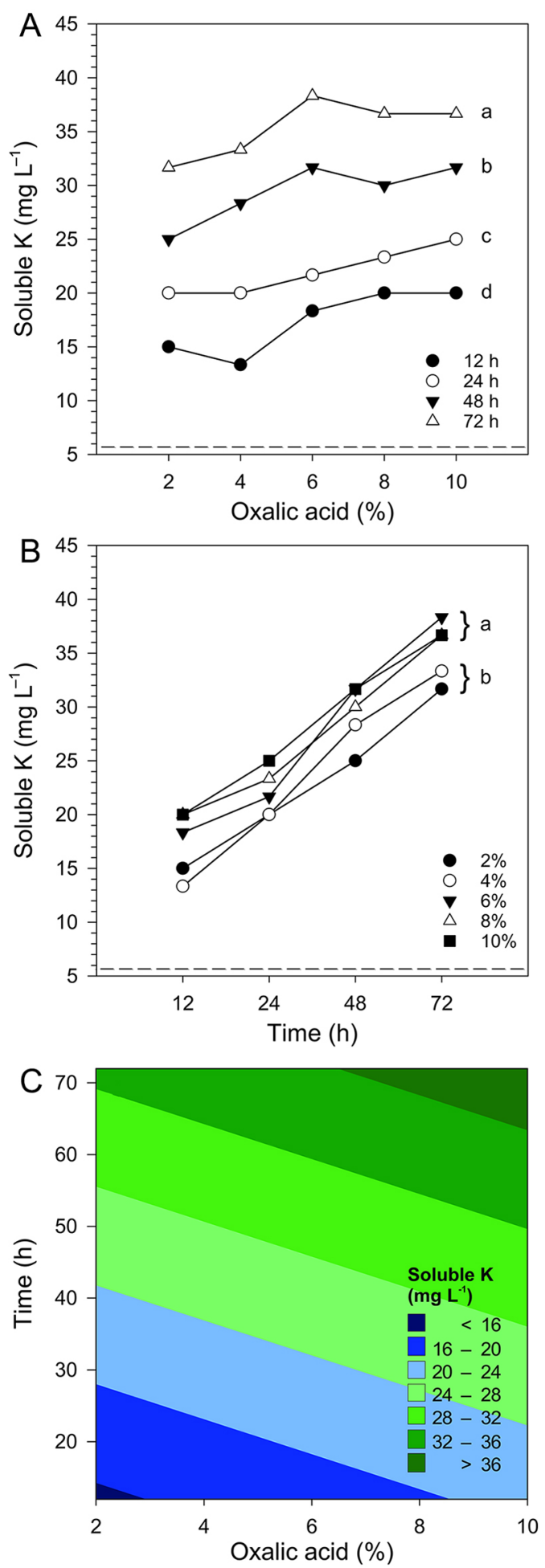

Figure 3 - Solubilized $K$ from Verdete in terms of oxalic acid concentration and reaction time. $\mathrm{A}$ and $\mathrm{B}$ compare the reaction times and oxalic acid concentrations, respectively. Treatments with the same letter are not significantly different (Tukey test, $p<0.05)$. C) Contour plot showing the combined effect of the variables on solubilized $K$ according to RSM. The dashed line represents control with distilled water. with oxalic acid was faster and extraction of $\mathrm{K}$ was $275 \%$ higher than citric acid after $120 \mathrm{~h}$ (Figure 2). The structure of oxalic acid $\left(\mathrm{C}_{2} \mathrm{H}_{2} \mathrm{O}_{4}\right)$ is composed of two adjacent carboxyl groups, which increases the dissociation constant $\left(\mathrm{p} K_{\mathrm{a} 1} 1.25, \mathrm{p} K_{\mathrm{a} 2} 3.81\right)$ (Lide, 2004; Riemenschneider and Tanifuji, 2011) and facilitates the formation of oxalate-metal complexes and the precipitation of metal oxalates, depending on the metal and the chemical conditions (Gadd et al., 2014; Sarver and Brinton, 1927; Sayer and Gadd, 1997). Acidulation of micaceous minerals promotes $\mathrm{K}$ release due to the replacement of $\mathrm{K}^{+}$by $\mathrm{H}^{+}$ions in the interlayer space of the mineral (Schimicoscki et al., 2020; Varadachari, 1997). Additionally, the removal of $\mathrm{Al}, \mathrm{Fe}$, and $\mathrm{Mg}$ cations from the octahedral sheet disturbs the morphology of glauconite, loosening the mineral structure (Hassan and Baioumy, 2006; Schimicoscki et al., 2020). Al-, Fe-, and $\mathrm{Mg}$-oxalate show very low aqueous solubility (Table 2) and, according to the chemical equilibrium model, more than $99 \%$ of $\mathrm{Al}, \mathrm{Fe}$, and $\mathrm{Mg}$ were complexed by oxalate at the experimental conditions used (Table $3)$. Therefore, oxalic acid could provide $\mathrm{H}^{+}$to replace $\mathrm{K}^{+}$and remove cations from the structure of micas in Verdete rock. Indeed, our XRD data suggested the formation of metal-oxalate complexes with metals in Verdete rock (such as $\mathrm{Al}, \mathrm{Fe}, \mathrm{Mg}, \mathrm{Mn}, \mathrm{Ni}$, and $\mathrm{Zn}$ ) and a change in mica crystallinity (Figure 4). On the other hand, solubility of K-oxalate is higher, differently from most metal oxalates (Table 2); thus, $\mathrm{K}^{+}$was released into the solution. The chemical equilibrium model predicted that $72 \%$ of $\mathrm{K}$ released was free $\mathrm{K}^{+}$and the remaining was complexed with oxalate (Table 3). However, the K-oxalate complex showed high activity (Table 3), suggesting that all $\mathrm{K}$ extracted from Verdete rock is available for plant uptake.

Citric acid can also contribute to acidulation of rocks and minerals; however, its capacity to form

Table 2 - Aqueous solubility of selected metal oxalates.

\begin{tabular}{llc}
\hline Metal & \multicolumn{1}{c}{ Oxalates } & Aqueous solubility \\
\hline $\mathrm{Al}$ & $\mathrm{Al}_{2}\left(\mathrm{C}_{2} \mathrm{O}_{4}\right)_{3}{ }^{\mathrm{a}}$ & Insoluble \\
\hline $\mathrm{Cr}$ & $\mathrm{CrC}_{2} \mathrm{O}_{4}{ }^{\mathrm{b}}$ & Soluble \\
\hline $\mathrm{Fe}$ & $\mathrm{FeC}_{2} \mathrm{O}_{4} \cdot 2 \mathrm{H}_{2} \mathrm{O}^{\mathrm{b}}$ & $0.078^{25}$ \\
& $\mathrm{Fe}_{2}\left(\mathrm{C}_{2} \mathrm{O}_{4}\right)_{3}{ }^{\mathrm{b}}$ & Soluble \\
\hline & $\mathrm{K}_{2} \mathrm{C}_{2} \mathrm{O}_{4} / \mathrm{K}_{2} \mathrm{C}_{2} \mathrm{O}_{4} \cdot \mathrm{H}_{2} \mathrm{O}^{\mathrm{b}}$ & $36.4^{20}$ \\
$\mathrm{~K}$ & $\mathrm{~K}_{3} \mathrm{Fe}_{2}\left(\mathrm{C}_{2} \mathrm{O}_{4}\right)_{3} \cdot 3 \mathrm{H}_{2} \mathrm{O}^{\mathrm{b}}$ & $4.7^{\mathrm{b}}$ \\
& $\left.\mathrm{K}_{2} \mathrm{TiO}_{2} \mathrm{C}_{2} \mathrm{O}_{4}\right)_{2}{ }^{a}$ & Soluble \\
\hline $\mathrm{Mg}$ & $\mathrm{MgC}_{2} \mathrm{O}_{4} / \mathrm{MgC}_{2} \mathrm{O}_{4} \cdot 2 \mathrm{H}_{2} \mathrm{O}^{\mathrm{b}}$ & $0.038^{25}$ \\
\hline $\mathrm{Mn}$ & $\mathrm{MnC}_{2} \mathrm{O}_{4} \cdot 2 \mathrm{H}_{2} \mathrm{O}^{\mathrm{b}}$ & $0.032^{20}$ \\
\hline $\mathrm{Ni}$ & $\mathrm{NiC}_{2} \mathrm{O}_{4}{ }^{a}$ & Insoluble \\
\hline $\mathrm{Zn}$ & $\mathrm{ZnC}_{2} \mathrm{O}_{4} / \mathrm{ZnC}_{2} \mathrm{O}_{4} \cdot 2 \mathrm{H}_{2} \mathrm{O}$ & $0.0026^{25}$ \\
\hline
\end{tabular}

Data obtained from ${ }^{\mathrm{O} O} \mathrm{O} N$ eil (2013) and bide (2004). cSolubility is expressed as the number of compound grams (excluding any water of hydration) that dissolve in $100 \mathrm{~g}$ of water. The temperature in ${ }^{\circ} \mathrm{C}$ is given as a superscript. Qualitative information on the solubility in water is given if quantitative data was unavailable. 


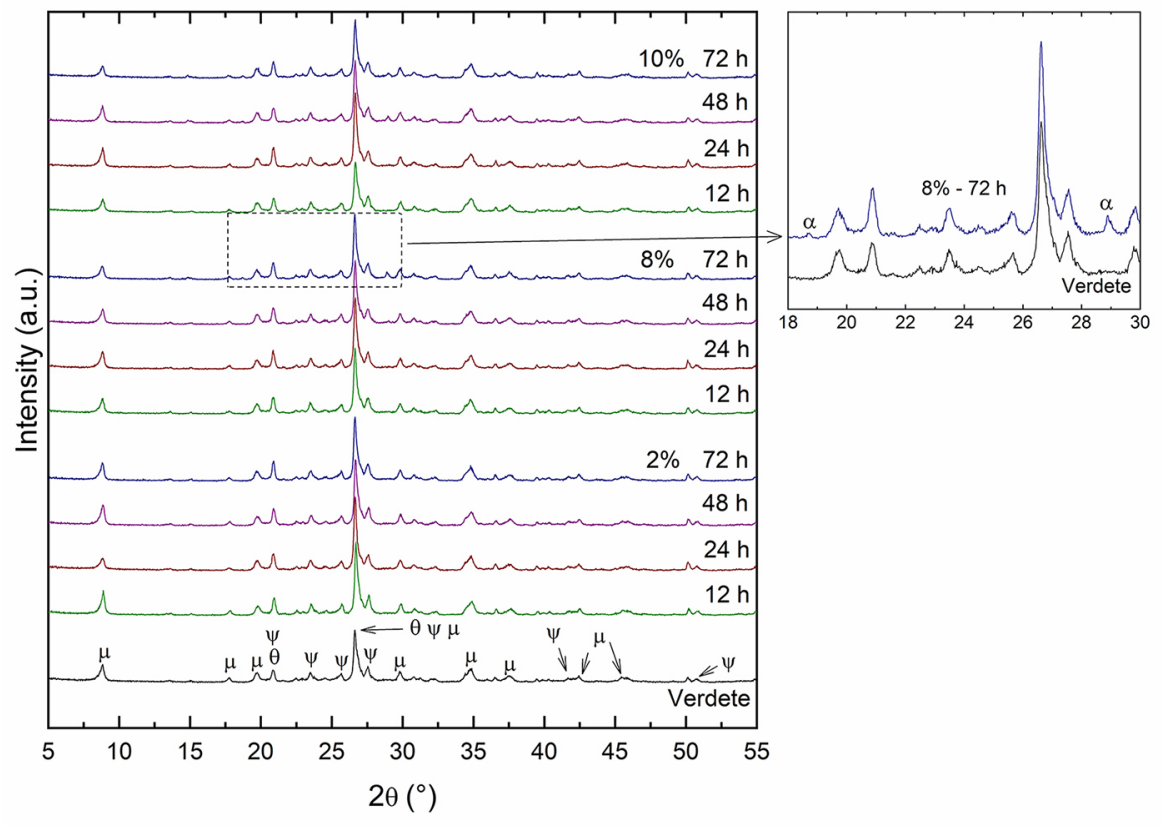

Figure 4 - X-ray diffractogram of Verdete rock and insoluble fractions of reaction products after attacking the rock with oxalic acid at 2, 8, and $10 \%$, for $12,24,48$ and 72 h. $\psi, \mu, \theta$, and $\alpha$ identify peaks corresponding to K-feldspar, muscovite/glauconite, quartz, and oxalate-metal complexes, respectively.

Table 3 - Estimated concentration and activity of the main chemical species formed by metals in Verdete rock in a solution of $2 \%$ $(\mathrm{m} / \mathrm{v})$ oxalic acid. Data were obtained from a simulation in Visual MINTEQ with concentrations of elements based on the addition of Verdete rock at $1 \%(\mathrm{~m} / \mathrm{v})$.

\begin{tabular}{|c|c|c|c|c|}
\hline Metal & Species name & $\begin{array}{c}\% \text { of total metal } \\
\text { Concentration }\end{array}$ & Concentration & Log activity \\
\hline & & & $\mathrm{mmol} \mathrm{L}^{-1}$ & \\
\hline $\mathrm{Al}$ & Al-(Oxalate) ${ }_{3}^{-3}$ & 99.80 & 31.405 & -1.907 \\
\hline $\mathrm{Fe}$ & Fe-(Oxalate) ${ }_{3}^{-3}$ & 99.97 & 8.5937 & -2.47 \\
\hline \multirow{2}{*}{ K } & $\mathrm{K}^{+1}$ & 72.40 & 17.332 & -1.808 \\
\hline & K-Oxalate ${ }^{-}$ & 27.55 & 6.5956 & -2.226 \\
\hline Mg & Mg-Oxalate & 99.42 & 7.6468 & -2.116 \\
\hline \multirow{2}{*}{$\mathrm{Mn}$} & Mn-(Oxalate) ${ }_{2}^{-2}$ & 64.60 & 0.005836 & -5.413 \\
\hline & Mn-Oxalate & 35.30 & 0.003189 & -5.495 \\
\hline $\mathrm{Ni}$ & $\mathrm{Ni}$-(Oxalate $)_{2}^{-2}$ & 99.43 & 0.01338 & -5.053 \\
\hline $\mathrm{Zn}$ & Zn-(Oxalate) ${ }_{2}^{-2}$ & 98.38 & 0.0004 & -6.397 \\
\hline
\end{tabular}

sparingly-soluble metal complexes is lower than that of oxalic acid (Gadd, 1999, 2017b; Lide, 2004). Contrary to oxalates, $\mathrm{Al}, \mathrm{Fe}-$, and $\mathrm{Mg}$-citrate complexes are watersoluble (Lide, 2004). Moreover, citric acid $\left(\mathrm{p} K_{\mathrm{a} 1} 3.13, \mathrm{p} K_{\mathrm{a} 2}\right.$ $\left.4.76, \mathrm{p} K_{\mathrm{a} 3} 6.40\right)$ is weaker compared to oxalic acid $\left(\mathrm{p} K_{\mathrm{a} 1}\right.$ 1.25, $\mathrm{p} K_{\mathrm{a} 2} 3.81$ ) (Lide, 2004). This explains the lower $\mathrm{K}$ extraction from Verdete rock by citric acid. Likewise, oxalic acid was superior to citric acid for phosphate extraction from various rock phosphates (Kpomblekou-A and Tabatabai, 1994, 2003; Mendes et al., 2020).
Oxalic acid is a key factor in microbial transformations of metals and minerals, playing an important role in element cycling, bioweathering, and formation of secondary minerals (Gadd, 2017a, b; Gadd et al., 2014). Fungal bioweathering of muscovite in laboratory and soil conditions has been observed, showing a network of channels formed by disruption of the mineral surface because of fungal hyphae growth, which was called fungal footprints (Wei et al., 2012). The authors attributed fungal footprints to a combination of physical and chemical mechanisms of mineral degradation, suggesting the participation of organic acids in the process. Our data support this observation, supplying evidence of the participation of organic acids, especially oxalic acid, in the dissolution of K-bearing silicate minerals.

$\mathrm{K}$ extraction from Verdete with oxalic acid was dependent on acid concentration and reaction time, which showed greater effect (Figure 2). At the intervals evaluated, the soluble $\mathrm{K}$ concentration nearly doubled by increasing reaction time from 12 to $72 \mathrm{~h}$. The low dissolution rate is one of the main constraints to apply silicate rocks directly to soil as nutrient sources to plants (Manning, 2018; Santos et al., 2015a). The dissolution rate in the soil depends on the physicochemical conditions and the microbial community, which can accelerate mineral decomposition through bioweathering mechanisms (Manning, 2018; Wei et al., 2012). The K released from Verdete by oxalic acid after $72 \mathrm{~h}$ represents an increase in dissolution roughly $1,000 \%$ over the control with distilled water $13.6 \mathrm{mg}$ 
$\mathrm{K}$ soluble $\mathrm{L}^{-1}$. Fungus Aspergillus niger can produce $38 \mathrm{~g}$ $\mathrm{L}^{-1}$ oxalic acid in only 10 days (Strasser et al., 1994), an amount greater than that used in this experiment $(20 \mathrm{~g}$ $\mathrm{L}^{-1}$ ). Therefore, the inoculation of oxalic acid-producing microorganisms to soils together with ground K-bearing silicate rock could improve $\mathrm{K}$ availability to plants. Soil inoculation of K-solubilizing microorganisms in combination with $\mathrm{K}$-feldspar increased $\mathrm{K}$ uptake by plants (Maity et al., 2014; Zhang and Kong, 2014). Furthermore, the weathering of silicate minerals in soil tends to be faster than predicted by laboratory experiments, possibly due to the action of soil microorganisms (Ciceri and Allanore, 2015; Manning, 2018).

Increasing oxalic acid concentration improved $\mathrm{K}$ extraction; however, a significant increase of soluble $\mathrm{K}$ was not observed above $6 \%$ of oxalic acid in the timeframe evaluated (Figure 3B). The equilibrium was not apparently reached at $72 \mathrm{~h}$; thus, predicting the effect of oxalic acid concentration after $72 \mathrm{~h}$ was not possible. During acid attack of rocks, high acid concentration can cause precipitation of reaction products on the surface of mineral particles, creating a layer that impairs solubilization reaction (Hatfield, 1964). Oxalic acid forms low-solubility complexes with metals in Verdete, such as $\mathrm{Al}, \mathrm{Fe}, \mathrm{Mg}, \mathrm{Mn}, \mathrm{Ni}$, and $\mathrm{Zn}$ (Table 2). XRD of the remaining solids after attacking of Verdete rock with oxalic acid suggested the formation of metal oxalates (Figure 4), which could impair the reaction, if they accumulate on the surface of mineral particles at high oxalic acid concentrations.

After $72 \mathrm{~h}$ of reaction, an extraction of up to $6.5 \%$ of $\mathrm{K}$ was reached in Verdete. Similar extraction rate was achieved in a chemolitotrophic bioleaching system after 49 days of cultivation of Acidithiobacillus thiooxidans (Matias et al., 2019). Thus, a chemoheterotrophic bioleaching based on oxalic acid-producing microorganisms could likely reach similar extraction rates in a shorter time. Biogenic oxalic acid has been used to recover several chemical elements from rocks, minerals, and wastes (Gadd, 1999, 2017a; Gharieb et al., 1998; Kang et al., 2019, 2020; Liang and Gadd, 2017; Sayer and Gadd, 1997; Suyamud et al., 2020; Vakilchap et al., 2016). Bioleaching can be performed in systems with direct contact between the microorganism and the rock or by applying microbial products as leaching agents (Goldstein et al., 1993; Johnson, 2014; Vakilchap et al., 2016). This research shows that oxalic acid is a promising microbial metabolite for such schemes, presenting the possibility of using microorganisms for $\mathrm{K}$ extraction in reactors or directly in the soil. $\mathrm{K}$ extraction in reactors could benefit from optimized conditions to reach high yield production of oxalic acid by microorganisms using carbohydrates as renewable energy sources (Strasser et al., 1994). On the other hand, $\mathrm{K}$ solubilization in the soil could produce additional benefits for plants due to other microbial mechanisms of plant-growth promotion, such as the production of phytohormones, phosphate solubilization, and stress relief (Araújo et al., 2020; Batista et al., 2018; Gupta and Pandey, 2019; Lubna et al., 2018; Zhang and Kong, 2014). Nevertheless, this strategy requires the development of formulations to allow efficient colonization and activity of the inoculated microorganism in the highly competitive soil environment (Herrmann and Lesueur, 2013; Malusá et al., 2012; Vassileva et al., 2020).

\section{Conclusions}

Oxalic acid can extract $\mathrm{K}$ from Verdete rock more efficiently than citric acid, possibly due to the formation of oxalate-metal complexes with metals in Verdete. The reaction is affected by oxalic acid concentration and time, which affects the amount of solubilized K.

\section{Acknowledgments}

The authors wish to thank Dr. Edmar Isaías de Melo for his assistance in the $\mathrm{K}$ analyses. This work was supported by the Brazilian National Council for Scientific and Technological Development /CNPq 401485/2016-1), the Minas Gerais State Agency for Research and Development (FAPEMIG APQ-0184217), the Coordination for the Improvement of Higher Level Personnel (CAPES, Finance Code 001), and the University Support Foundation (FAU 02/2018).

\section{Authors' Contributions}

Conceptualization: Duarte, L.M.; Mendes, G.O.; Ávila Neto, C.N. Data acquisition: Duarte, L.M.; Xavier, L.V.; Rossati, K.F.; Oliveira, V.A.; Schimicoscki, R.S. Data analysis: Duarte, L.M.; Mendes, G.O.; Ávila Neto, C.N. Design of methodology: Duarte, L.M.; Mendes, G.O.; Ávila Neto, C.N. Writing and editing: Duarte, L.M.; Mendes, G.O.; Ávila Neto, C.N.

\section{References}

Araújo, V.C.; Rossati, K.F.; Xavier, L.V.; Oliveira, V.A.; Carmo, G.J.S.; Assis, G.A.; Mendes, G.O. 2020. Enhanced growth in nursery of coffee seedlings inoculated with the rhizosphere fungus Aspergillus niger for field transplantation. Rhizosphere 15: 100236

Associação Nacional para Difusão de Adubos [ANDA]. 2017. Fertilizers: 2017 Statistics = Setor de Fertilizantes: Anuário Estatístico 2017. Associação Nacional para Difusão de Adubos, São Paulo, SP, Brazil (in Portuguese).

Batista, B.D.; Lacava, P.T.; Ferrari, A.; Teixeira-Silva, N.S.; Bonatelli, M.L.; Tsui, S.; Mondin, M.; Kitajima, E.W.; Pereira, J.O.; Azevedo, J.L.; Quecine, M.C. 2018. Screening of tropically derived, multi-trait plant growth-promoting rhizobacteria and evaluation of corn and soybean colonization ability. Microbiological Research 206: 33-42.

Ciceri, D.; Allanore, A. 2015. Microfluidic leaching of soil minerals: release of $\mathrm{K}^{+}$from $\mathrm{K}$ feldspar. PLoS One 10: e0139979. 
Ciceri, D.; Allanore, A. 2020. Nutrient release from K-feldspar ore altered in hydrothermal conditions. Chemical Papers 74: 431-440.

Ciceri, D.; Oliveira, M.; Allanore, A. 2017. Potassium fertilizer via hydrothermal alteration of K-feldspar ore. Green Chemistry 19: 5187-5202.

Departamento Nacional de Produção Mineral [DNPM]. 2018. Mineral Summary $2016=$ Sumário mineral 2016. Departamento Nacional de Produção Mineral, Brasília, DF, Brazil (in Portuguese).

Gadd, G.M. 1999. Fungal production of citric and oxalic acid: importance in metal speciation, physiology and biogeochemical processes. Advances in Microbial Physiology 41: 47-92.

Gadd, G.M. 2007. Geomycology: biogeochemical transformations of rocks, minerals, metals and radionuclides by fungi, bioweathering and bioremediation. Mycological Research 111: 3-49.

Gadd, G.M. 2017a. The geomycology of elemental cycling and transformations in the environment. Microbiology Spectrum 5: 1-16.

Gadd, G.M. 2017b. Fungi, rocks, and minerals. Elements 13: 171176.

Gadd, G.M.; Bahri-Esfahani, J.; Li, Q.; Rhee, Y.J.; Wei, Z.; Fomina, M.; Liang, X. 2014. Oxalate production by fungi: significance in geomycology, biodeterioration and bioremediation. Fungal Biology Reviews 28: 36-55.

Gharieb, M.M.; Sayer, J.A.; Gadd, G.M. 1998. Solubilization of natural gypsum (CaSO4.2H2O) and the formation of calcium oxalate by Aspergillus niger and Serpula himantioides. Mycological Research 102: 825-830.

Goldstein, A.H.; Rogers, R.D.; Mead, G. 1993. Mining by microbe. Nature Biotechnology 11: 1250-1254.

Gupta, S.; Pandey, S. 2019. ACC deaminase producing bacteria with multifarious plant growth promoting traits alleviates salinity stress in French Bean (Phaseolus vulgaris) plants. Frontiers in Microbiology 10: 1-17.

Hassan, M.S.; Baioumy, H.M. 2006. Structural and chemical alteration of glauconite under progressive acid treatment. Clays and Clay Minerals 54: 491-499.

Hatfield, J.D. 1964. Normal superphosphate: chemistry. p. 116130. In: U.S. Department of Agriculture, eds. Superphosphate: its history, chemistry, and manufacture. USDA, Washington, DC, USA.

Herrmann, L.; Lesueur, D. 2013. Challenges of formulation and quality of biofertilizers for successful inoculation. Applied Microbiology and Biotechnology 97: 8859-8873.

Johnson, D.B. 2014. Biomining: biotechnologies for extracting and recovering metals from ores and waste materials. Current Opinion in Biotechnology 30: 24-31.

Kang, X.; Csetenyi, L.; Gadd, G.M. 2019. Biotransformation of lanthanum by Aspergillus niger. Applied Microbiology and Biotechnology 103: 981-993.

Kang, X.; Csetenyi, L.; Gadd, G.M. 2020. Monazite transformation into Ce- and La-containing oxalates by Aspergillus niger. Environmental Microbiology 22: 1635-1648.

Kpomblekou-A, K.; Tabatabai, M.A. 1994. Effect of organic acids on release of phosphorus from phosphate rocks. Soil Science 158: $442-453$
Kpomblekou-A, K.; Tabatabai, M.A. 2003. Effect of lowmolecular weight organic acids on phosphorus release and phytoavailabilty of phosphorus in phosphate rocks added to soils. Agriculture, Ecosystems \& Environment 100: 275284.

Liang, X.; Gadd, G.M. 2017. Metal and metalloid biorecovery using fungi. Microbial Biotechnology 10: 1199-1205.

Lide, D.R. 2004. CRC Handbook of Chemistry and Physics. 85ed. CRC Press, Boca Raton, FL, USA.

Lopes-Assad, M.L.; Avansini, S.H.; Rosa, M.M.; Carvalho, J.R.P.; Ceccato-Antonini, S.R.; Carvalho, J.R.P.; Antonini, S.R.C.; Ceccato-Antonini, S.R. 2010. The solubilization of potassiumbearing rock powder by Aspergillus niger in small-scale batch fermentations. Canadian Journal of Microbiology 56: 598-605.

Lubna; Asaf, S.; Hamayun, M.; Gul, H.; Lee, I.-J.; Hussain, A. 2018. Aspergillus niger CSR3 regulates plant endogenous hormones and secondary metabolites by producing gibberellins and indoleacetic acid. Journal of Plant Interactions 13: 100-111.

Luz, A.B.; Lapido-Loureiro, F.E.; Sampaio, J.A.; Castilhos, Z.C.; Bezerra, M.S. 2010. Ores, minerals and technological routes for producing alternative fertilizers $=$ Rochas, minerais e rotas tecnológicas para a produção de fertilizantes alternativos. p. 61-88. In: Fernandes, F.R.C.; Luz, A.B.; Castilhos, Z.C., eds. Agrominerals for Brazil = Agrominerais para o Brasil. CETEM/MCT, Rio de Janeiro, RJ, Brazil (in Portuguese).

Maity, A.; Pal, R.K.; Chandra, R.; Singh, N.V. 2014. Penicillium pinophilum: a novel microorganism for nutrient management in pomegranate (Punica granatum L.). Scientia Horticulturae 169: 111-117.

Malusá, E.; Sas-Paszt, L.; Ciesielska, J. 2012. Technologies for beneficial microorganisms inocula used as biofertilizers. The Scientific World Journal 2012: 491206.

Manning, D.A.C. 2018. Innovation in resourcing geological materials as crop nutrients. Natural Resources Research 27: 217-227.

Matias, P.C.; Mattiello, E.M.; Santos, W.O.; Badel, J.L.; Alvarez V, V.H. 2019. Solubilization of a K-silicate rock by Acidithiobacillus thiooxidans. Minerals Engineering 132: 69-75.

Mendes, G.O.; Murta, H.M.; Valadares, R.V.; Silveira, W.B.; Silva, I.R.; Costa, M.D. 2020. Oxalic acid is more efficient than sulfuric acid for rock phosphate solubilization. Minerals Engineering 155: 106458.

Mendes, G.O.; Dias, C.S.; Silva, I.R.; Júnior, J.I.R.; Pereira, O.L.; Costa, M.D. 2013. Fungal rock phosphate solubilization using sugarcane bagasse. World Journal of Microbiology and Biotechnology 29: 43-50.

Moreira, D.S.; Uhlein, A.; Fernandes, M.L.S.; Mizusaki, A.M.; Galéry, R.; Delbem, I.D. 2016. Stratigraphy, petrography and potassium mineralization in green siltstones of the Bambuí group in the region of São Gotardo, Minas Gerais = Estratigrafia, petrografia e mineralização de potássio em siltitos verdes do grupo bambuí na região de São Gotardo, Minas Gerais. Geociências 35: 157-171 (in Portuguese).

Myers, R.H.; Montgomery, D.C.; Anderson-Cook, C.M. 2016. Response Surface Methodology: Process and Product Optimization Using Designed Experiments. 4ed. John Wiley, Hoboken, USA. 
O'Neil, M.J. 2013. The Merck Index: An Encyclopedia of Chemicals, Drugs, and Biologicals. 15ed. The Royal Society of Chemistry, Cambridge, UK.

Pessoa, R.S.; Silva, C.A.; Moretti, B.S.; Furtini Neto, A.E.; Inda, A.V.; Curi, N. 2015. Solubilization of potassium from alternative rocks by humic and citric acids and coffee husk. Ciência e Agrotecnologia 39: 553-564.

Riemenschneider, W.; Tanifuji, M. 2011. Oxalic acid. p. 529-541. In: Ullmann's Encyclopedia of Industrial Chemistry. Wiley$\mathrm{VCH}$, Weinheim, Germany.

Safatle, F.A.; Oliveira, K.D.; Ávila Neto, C.N. 2020. Potassium recovery from Brazilian glauconitic siltstone by hydrothermal treatments. REM-International Engineering Journal 73: 213224.

Santos, W.O.; Mattiello, E.M.; Costa, L.M.; Abrahão, W.A.P.; Santos, W.O.; Mattiello, E.M.; Costa, L.M.; Abrahão, W.A.P. 2015a. Characterization of verdete rock as a potential source of potassium. Revista Ceres 62: 392-400.

Santos, W.O.; Mattiello, E.M.; Costa, L.M.; Abrahão, W.A.P.; Novais, R.F.; Cantarutti, R.B. 2015b. Thermal and chemical solubilization of verdete for use as potassium fertilizer. International Journal of Mineral Processing 140: 72-78.

Sarver, L.A.; Brinton, P.H.M.-P. 1927. The solubility of some rareearth oxalates. Journal of the American Chemical Society 49: 943-958.

Sayer, J.A.; Gadd, G.M. 1997. Solubilization and transformation of insoluble inorganic metal compounds to insoluble metal oxalates by Aspergillus niger. Mycological Research 101: 653661.

Schimicoscki， R.S.; Oliveira， K.D.; Ávila-Neto, C.N. 2020. Potassium recovery from a Brazilian glauconitic siltstone via reaction with sulfuric acid in hydrothermal conditions. Hydrometallurgy 191: 105251.
Strasser, H.; Burgstaller, W.; Schinner, F. 1994. High-yield production of oxalic acid for metal leaching processes by Aspergillus niger. FEMS Microbiology Letters 119: 365-370.

Stumm, W. 1986. Coordinative interactions between soil solids and water: an aquatic chemist's point of view. Geoderma 38: 19-30.

Suyamud, B.; Ferrier, J.; Csetenyi, L.; Inthorn, D.; Gadd, G.M. 2020. Biotransformation of struvite by Aspergillus niger: phosphate release and magnesium biomineralization as glushinskite. Environmental Microbiology 22: 1588-1602.

Tollefson, J. 2010. Food: The global farm. Nature 466: 554-556.

Vakilchap, F.; Mousavi, S.M.; Shojaosadati, S.A. 2016. Role of Aspergillus niger in recovery enhancement of valuable metals from produced red mud in Bayer process. Bioresource Technology 218: 991-998.

Varadachari, C. 1997. Potash fertilizer from biotite. Industrial and Engineering Chemistry Research 36: 4768-4773.

Vassileva, M.; Flor-Peregrin, E.; Malusá, E.; Vassilev, N. 2020. Towards better understanding of the interactions and efficient application of plant beneficial prebiotics, probiotics, postbiotics and synbiotics. Frontiers in Plant Science 11: 1068.

Wei, Z.; Kierans, M.; Gadd, G.M. 2012. A model sheet mineral system to study fungal bioweathering of mica. Geomicrobiology Journal 29: 323-331.

Xue, X.; Zhang, L.; Peng, Y.; Li, P.; Yu, J. 2019. Effects of mineral structure and microenvironment on $\mathrm{K}$ release from potassium aluminosilicate minerals by Cenococcum geophilum fr. Geomicrobiology Journal 36: 11-18.

Zhang, C.; Kong, F. 2014. Isolation and identification of potassiumsolubilizing bacteria from tobacco rhizospheric soil and their effect on tobacco plants. Applied Soil Ecology 82: 18-25. 